\title{
Naticid gastropod and octopodid cephalopod predatory traces: evidence of drill holes on the leucosid crab Ristoria pliocaenica (Ristori, 1891), from the Pliocene of the "La Serra" quarry (Tuscany, Italy)
}

\begin{abstract}
Garassino et al. (2012) reported on a rich community of decapod crustaceans including axiideans, gebiideans, anomurans, and brachyurans from the Zanclean (Early Pliocene) of the "La Serra" quarry near San Miniato (Pisa, Tuscany, central Italy). In this decapod-rich assemblage some carapaces of the common pebble crab Ristoria pliocaenica (Ristori, 1891) (Leucosiidae Samouelle, 1819) are drilled in characteristic ways, due to the predatory activity of individuals belonging to two different taxa of marine clades, possibly naticids (Gastropoda, Naticoidea), and to octopodids (Cephalopoda, Octopoda). This is the first report of direct evidence of predation by cephalopods on crabs in the fossil record.
\end{abstract}

Key words: Naticid, Octopodid, Predation, Leucosiidae, Pliocene, Italy.

Riassunto - Tracce di predazione di gasteropodi naticidi e cefalopodi octopodidi: evidenza di perforazioni in Ristoria pliocaenica (Ristori, 1891) (Leucosiinae), nel Pliocene della cava "La Serra", San Miniato (Toscana, Italia).

Garassino et al. (2012) hanno descritto una ricca associazione a crostacei decapodi (axiidi, gebiidi, anomuri e brachiuri) del Pliocene inferiore (Zancleano) della cava "La Serra" presso San Miniato (Pisa, Toscana, Italia centrale). Nella ricca associazione a decapodi, alcuni carapaci di Ristoria pliocaenica (Ristori, 1891) (Leucosiidae Samouelle, 1819) risultano trapanati in maniera caratteristica per la predazione da parte di almeno due differenti taxa di molluschi marini attribuibili a naticidi (Gastropoda, Naticoidea) e a octopodidi (Cephalopoda, Octopoda). Questa è la prima testimonianza fossile diretta della predazione da parte di cefalopodi nei confronti di crostacei decapodi.

Parole chiave: Naticidi, Octopodidi, Predazione, Leucosiidae, Pliocene, Italia.

\footnotetext{
* Via Alessandro Volta 16, I-22070 Appiano Gentile (Como), Italy; e-mail: juanaldopasini@tiscali.it

** Museo di Storia Naturale di Milano, Corso Venezia 55, 20121 Milano, Italy; e-mail: alessandro.garassino@comune.milano.it; alegarassino@gmail.com
} 


\section{Introduction and geological setting}

Direct evidence of predation on decapod crustaceans is very rare in the fossil record and generally limited to the feeding behavior of some vertebrate predators, commonly fishes (Boucot, 1990). Indeed, only some studies are known. For example Nybelin (1958) reported on some indeterminate, badly preserved crustacean remains in the digestive tract of predator fishes from the Late Jurassic lithographic limestones of Bavaria, southern Germany; Grande (1984) signaled the presence of indeterminate crustacean remains in the digestive tract of predatory fishes from the Eocene Green River Formation in Wyoming, United States; Maisey (1991) and Maisey \& De Carvalho (1995) documented the presence of decapods and brachyuran larvae in the stomach of some fishes from the Santana Formation of Brazil (mid-Cretaceous); and Pasini \& Garassino (2011) reported on a brachyuran decapod swallowed by a cat fish shark, preserved inside the stomach of the predator coming from the sub-lithographic limestones of Lebanon (Cenomanian, Late Cretaceous). Furthermore, Klompmaker (2011: 49) figured in a short note a loose dactylus of a brachyuran crab ("... possibly Cancer sp.."), showing a rounded "drill hole of a predator snail", from the Pliocene of Langenboom (The Netherlands). Finally, Ossó \& Stalennuy $(2011: 45,46)$ reported on a decapod fauna from the middle Miocene of Ukraine in which part of the brachyuran specimens are suspected, in speculative way, to have been predated by possible indeterminate octopodid cephalopods, but, unfortunately, no direct evidence is documented to support this hypothesis.

The specimens from this study come from the "La Serra" quarry, located along a hill $5 \mathrm{~km}$ south of the San Miniato (Pisa, Tuscany, central Italy). Close examinations of the mollusk assemblage in addition to sedimentological and micropaleontological data, allow dating the layers of the "La Serra" quarry to the Early Pliocene (Zanclean) (Garassino et al., 2012). This community includes an unusual decapod-rich fauna of axiideans, gebiideans, anomurans, and brachyurans (for complete list see Garassino et al., 2012: 16). The faunal assemblage is indicative of an environment of shallow sublittoral water, with sandy-muddy bottoms and shell beds, partially covered or near a sea grass vegetation, probably similar to the extant Mediterranean Posidonia beds (Garassino et al., 2012).

The goal of this study is to report on the peculiar, direct evidence of predation in this community on some specimens of the pebble crab Ristoria pliocaenica (Ristori, 1891) (Leucosiidae Samouelle, 1819) by two different clades of invertebrate carnivorous predators. Among the associated mollusk fauna, carnivorous gastropods such as muricids and mainly naticids are presents: Natica (Naticarius) tigrina (Defrance, 1825); Tectonatica prietoi (Hidalgo, 1873); Tectonatica astensis (Sacco, 1890); Cochlis raropunctata (Sasso, 1827); Neverita josephina (Risso, 1826); Natica sp. (sensu Garassino et al., 2012). They are active predators in this environment, as documented by the presence of hundreds of gastropod and bivalve shells pertaining to different species containing drill holes. Naticid boreholes have a typical rounded form (not exclusively, for instance nudibranchs produce similar drill holes, but the holes are smaller, see short discussion in Klompmaker, 2012) with a tronco-conical cross section, with the maximum diameter on the outer surface of the shell and inclined concave walls. Their predatory traces are documented in the marine assemblages from the Cretaceous (Kelley \& Hansen, 2003) to the Recent around the world (Boucot, 1990), and it has been reported from 
the Pliocene of Italy as well (e.g. Robba \& Ostinelli, 1975; Pasini \& Garassino, 2006). Among the fauna of the "La Serra" quarry, similar complete drill holes are present on the carapace of one specimen of the pebble crab Ristoria pliocaenica, whereas another specimen shows a possible incomplete drill hole. Additionally, the predatory activity of an indeterminate octopodid cephalopod is here suggested by the presence of characteristic millimeter-sized sub-elliptic drill holes (Wodinsky, 1969; Robba \& Ostinelli, 1975) on the carapace of seven other specimens of $R$. pliocaenica.

\section{Material}

Nine loose, nearly complete, small-sized, three-dimensionally preserved carapaces ascribed to Ristoria pliocaenica, originate from the clayey sands of the upper most part of the "La Serra" quarry (Unit 4), Early Pliocene (Zanclean) in age appear to contain damages (GPDG 0174; GPDG 0175a-g; GPDG 0198).

Casts of the boreholes and drill holes were made by using silicon resin.

Seven selected specimens of drilled-bivalves and six drilled-gastropods, originating from the same layers, were also included for comparison.

Bivalve specimens: Glans intermedia (Brocchi, 1814) (GPDG 0228); Glycymeris glycymeris (Linnaeus, 1758) (GPDG 0229); Megaxinus transversus (Bronn, 1831) (GPDG 0230); Pitar rudis (Poli, 1795) (GPDG 0231); Plagiocardium papillosum (Poli, 1795) (GPDG 0232); Striarca lactea (Linnaeus, 1758) (GPDG 0233); Venus multilamella (Lamarck, 1818) (GPDG 0234).

Gastropods specimens: Bolinus brandaris torularius (Lamarck, 1822) (GPDG 0235); Cochlis raropunctata raropunctata (Sasso, 1827) (GPDG 0236); Hexaplex trunculus (Linnaeus, 1758) (GPDG 0237); Niso eburnea (Risso, 1826) (GPDG 0238); Tribia uniangulata (Deshayes, 1830) (GPDG 0239); Turricula intermedia (Bronn, 1831) (GPDG 0240).

The specimens are housed in the Palaeontological Collections of the Gruppo Paleontologico "C. De Giuli”, Biblioteca Comunale Vallesiana, Castelfiorentino, (Firenze, Italy) (GPDG).

\section{Description of crab specimens drilled by gastropods}

One incomplete carapace of Ristoria pliocaenica (GPDG 0175a - width: $10.7 \mathrm{~mm}$ ), lacking the frontal part, exhibits a complete drill hole in the cuticle of the middle posterior part of the cardiac region. The drill hole is rounded (outer diameter $2.5 \mathrm{~mm}$ ), wider on the outer surface, narrower in the inner part, troncoconical in transverse section and with slightly concave walls, and showing a beveled edge on the outer diameter, as is typical for naticid drill holes and present in many naticid drill holes (e.g. Carriker, 1981; Klompmaker, 2012: 117) (Fig. 1A).

One complete carapace of $R$. pliocaenica (GPDG 0175b - length: $11.7 \mathrm{~mm}$; width: $10 \mathrm{~mm}$ ), bearing a small rounded incomplete smooth and concave drill hole on the dorsal epicuticle (outer diameter $0.9 \mathrm{~mm}$ ) on the posterior part of the left metabranchial region, referable to an ?incomplete attack, likely due to the predation by a gastropod (Fig. 1B). There is no evidence of the central boss often present in the naticid incomplete drill holes (Klompmaker, 2012) (Fig. 1B). 

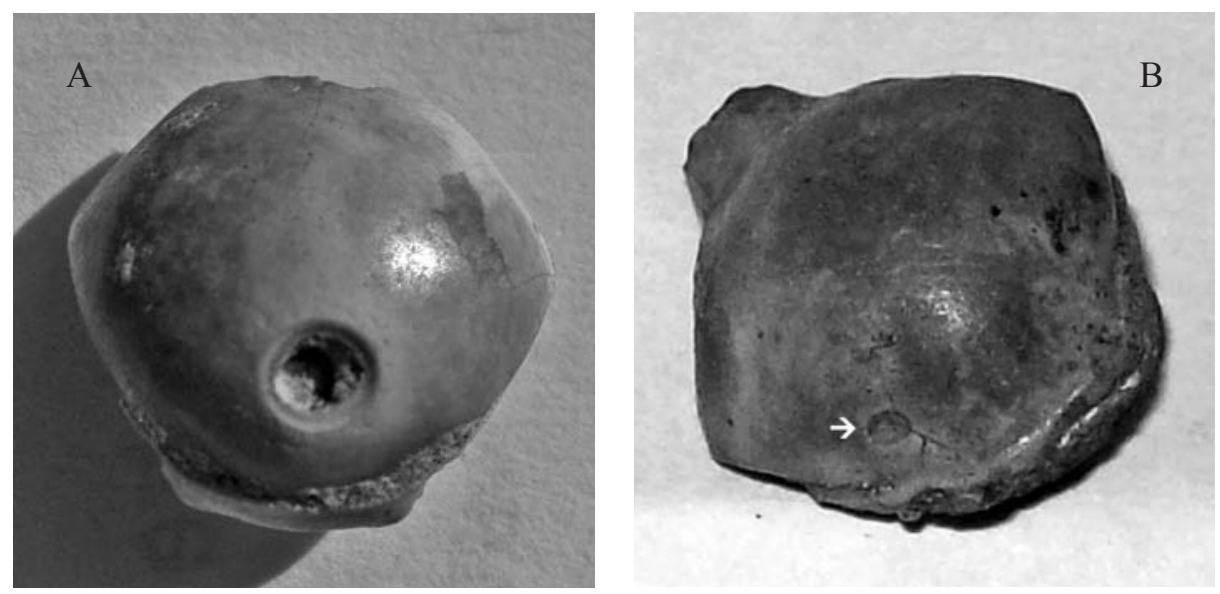

Fig. 1 - A) Complete drill hole by naticid predation on Ristoria pliocaenica, GPDG 0175a / Foro di predazione completo di naticide su Ristoria pliocaenica, GPDG 0175a (x 4.4). B) Incomplete drill hole by putative naticid attack on Ristoria pliocaenica, GPDG 0175b (see the arrow) / Foro di predazione incompleto di possibile naticide su Ristoria pliocaenica, GPDG 0175b (freccia) (x 5.77).

The morphological characters of these holes are typical of drill holes attributed to naticid gastropods (Robba \& Ostinelli, 1975; Boucot, 1990; Pasini \& Garassino, 2006), and can be ascribed to the ichnospecies Oichnus paraboloides Bromley, 1981. Moreover, any other possible predator has been detected among the "La Serra" quarry mollusk fauna, excluding muricid gastropods. Muricid drill holes differ in shape by commonly more irregular outlines exhibiting typically cylindrical cross section with vertical walls (e.g. Kabat, 1990). A selected sample of different gastropod and bivalve shells showing a similar drill hole morphology is also figured for morphological comparison (Fig. 2A-D).

\section{Description of crab specimens drilled by octopodid cephalopods}

Seven complete carapaces of Ristoria pliocaenica (GPDG 0174; GPDG 0175c-g; GPDG 0198 - around $11 \mathrm{~mm}$ length, $10 \mathrm{~mm}$ wide) showing evidence of predatory attacks on the dorsal side, evidenced by small completely drilled ovoidal to elliptical submillimeter-sized drill holes (maximum diameter 0.4 $\mathrm{mm}$ ) with a conical cross section (Fig. 3A-B). Four specimens are drilled in the right anterolateral region, one in the left anterolateral margin, and two near the right central cardiac region (Fig. 4). These holes are similar in size and shape to those produced by octopodid cephalopods in fossil (Robba \& Ostinelli, 1975; Harper, 2002) and extant bivalve and gastropod shells (Wodinsky, 1969; Nixon, 1979; Nixon \& Macconnachie, 1988) and crabs (Boyle \& Knobloch, 1981). This behavior of preying upon on gastropods and, less commonly, on crabs (Boyle \& Knobloch, 1981; Wirtz, 1998; Key et al., 2002) is also directly observed from some Octopus in nature and captivity. Similar drill holes of predation were recognized only on the reported specimens of the pebble crab Ristoria pliocaenica, among the rich and diversified fauna from the "La Serra" quarry. 

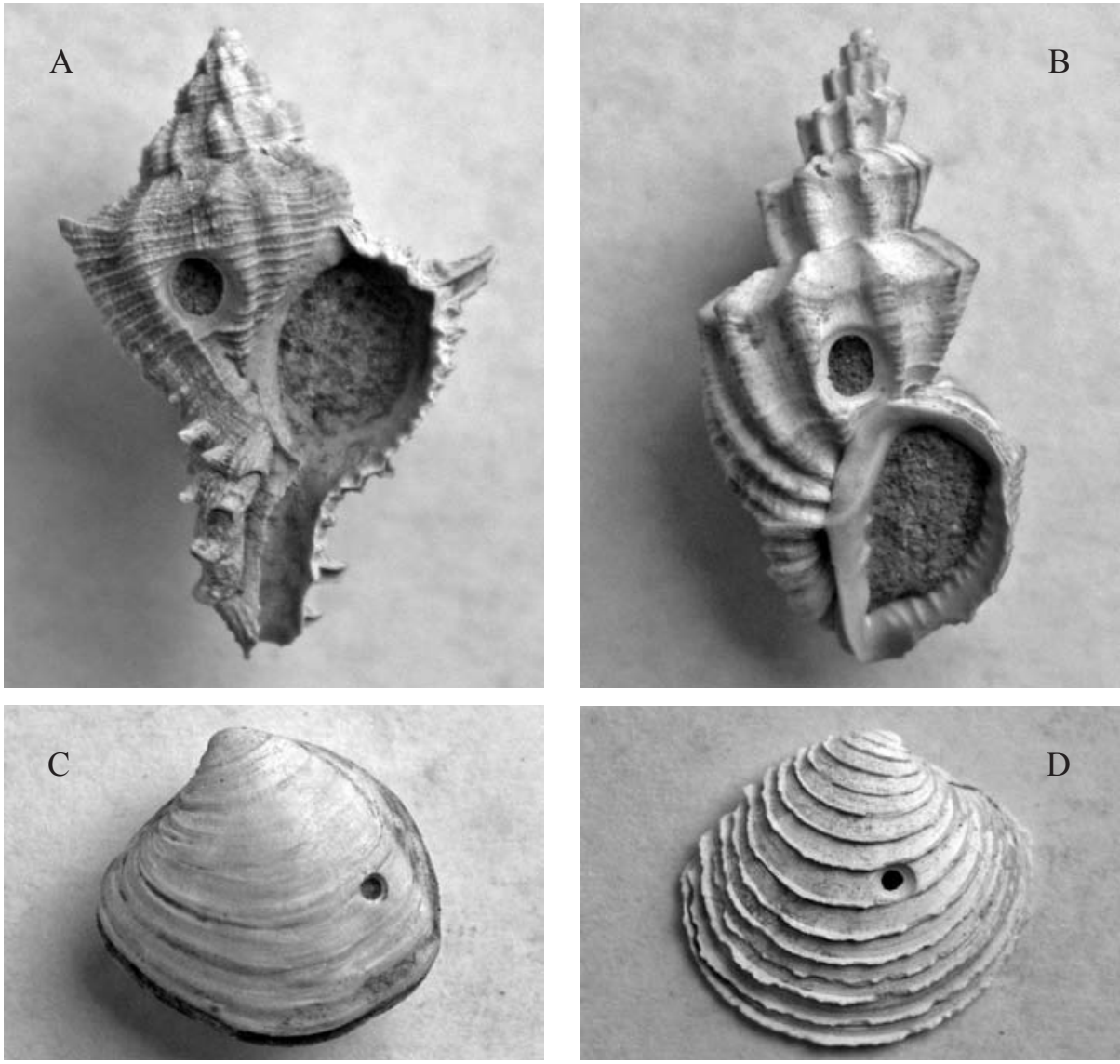

Fig. 2 - Boreholes by naticid predation on gastropod and bivalve shells / Fori di predazione di naticidi su conchiglie di gasteropodi e bivalvi. A) Hexaplex trunculus (GPDG 0237) (x 3.14). B) Tribia uniangulata (GPDG 0239) (x 3.28). C) Megaxinus transversus (GPDG 0230) (x 2.38). D) Venus multilamella (GPDG 0234) (x 2.24).
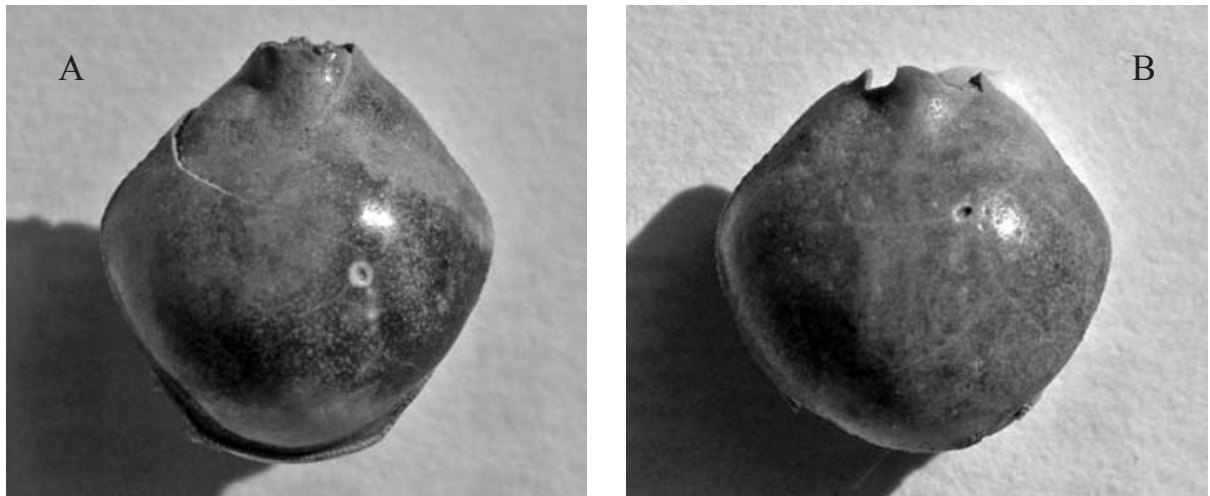

Fig. 3 - Complete drill-hole by octopodid predation on Ristoria pliocaenica. / Foro completo di octopode su Ristoria pliocaenica. A) GPDG 0175e (x 4.21). B) GPDG 0175f (x 4.44). 


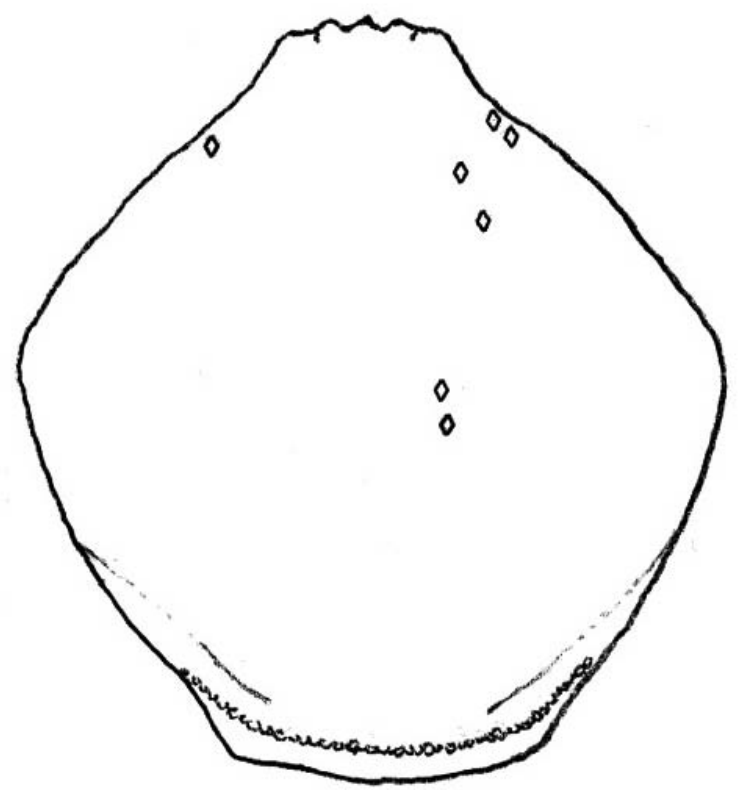

Fig. 4 - Line drawing of Ristoria pliocaenica showing the distribution of the octopodid drill holes on carapace dorsal surface / Disegno al tratto di Ristoria pliocaenica con la distribuzione dei diversi fori di predazione da parte di octopodi sulla superficie dorsale del carapace.

\section{Discussion}

Two different evidences of predatory behavior by mollusks on decapod crustaceans were recognized from the rich assemblage of the "La Serra" quarry. Unfortunately, the mollusk-rich assemblage from the "La Serra" quarry has not yet been studied and only an incomplete list of gastropods and bivalves were reported by Garassino et al. (2012: 47; Table 1). Although others potential culprits (see Kowalewski, 1993: 72, 73, Tab. 1) that usually drill into mollusks, are also presents in the faunal assemblage (e.g. Muricidae), as previously reported, their drill holes are only occasionally similar to those of naticids. Moreover, non-predatory trace of shell-boring fungi, algae and hydrozoans (commensalist, mutualist, host-parasitic) are also reported from the fossil record (see Boucot, 1990: 347-361), but these traces are very different in shape, and outline, and they cannot be confused with those observed on the specimens.

\section{Gastropod drill holes}

The drilling behavior of the naticids is here documented by the typical morphology of the drill holes on the carapace of two specimens (Figs. 1A-B). Extant naticids are active carnivorous predators searching for food mostly burrowing in the bottom and only sometimes on the top of the bottom (Kelley \& Hansen, 2003: 144). Especially the naticid boreholes have a typical rounded form with a 
conical cross section and concave walls, with maximum diameter on the outer surface of the shell Boucot, 1990: 165, fig.142; Kabat, 1990). During the attack the prey is enveloped by the mantle and bored using alternately the "accessory boring organ" (ABO) which emits a chemical secretion and the corneous radula (Carriker, 1969). Finally, the prey is ingested directly through the drill hole. Usually the prey of these gastropods are others gastropods (also of the same species) or bivalves. Studies carried out the predatory behavior of some species of extant naticids seem to show that predation occurs in the bottoms and that the mollusk preys are selected and bored mainly in particular areas of the shell, depending for typology and size (Kabat, 1990: 171,172). Moreover, differences in shape are reported among drill holes created by different species of naticids: "... there is a species-specific component to borehole geometry, ... because the index of borehole functionality may differ between species" (Grey et al., 2005: 255). These differences are also observed among the specimens pertaining to a different geological age. The rarity of crab specimens preyed in this way at the "La Serra" quarry (only one specimen shows a complete drill hole among over hundred of specimens of carapace from the pebble crab Ristoria pliocaenica examined) in an outcrop that is rich in resources of food for naticid (such as bivalves and gastropods), allows suggesting that these attacks may have been a possible mistake, or scarce selection of the prey. This peculiar behavior may also be induced by the form and dimensions of the carapace of the prey, the curvature somewhat resembling the shell of many mollusk presents in the same beds, especially when the crab is partially embedded in the soft sediments. It may be speculated that the general rounded shape of the smooth carapace of these pebble crabs, when partially exposed, may have caused occasional confusion for the predator. Indeed only one drill hole is complete (GPDG 0175a) while the other one was abandoned (GPDG 0175b). Contrasting to that evidence, experiments on living naticid species "established that naticids are selective predators choosing prey with the lowest cost-to-benefit ratio" (Kitchell et al., 1981: 533). Moreover, it is interesting to point out that only the fossorial specimens of $R$. pliocaenica, among the decapod-rich fauna (for complete list see Garassino et al., 2012), were drilled by carnivorous gastropods. Other, less common fossorial decapod brachyurans (Atelecyclus, Ilia, Liocarcinus), and the common burrower (Goneplax), do not show traces of this kind of predation (G. Pasini, personal obs., 2011). So, in our opinion, these scarce drill holes probably represent only an occasional predatory behavior among naticids in fossil and extant species. Indeed, to our knowledge, there is no report in the literature of this type of predation of naticids on fossil leucosid crabs.

\section{Octopodid drill holes}

Crabs are part of the diet of extant octopodid cephalopods, but they have never been formally reported from the fossil record. Among Octopodidae the predatory behavior of extant Octopus is well known and documented (e.g. Wodinsky, 1969; Nixon \& Macconnachie, 1988). Octopus mainly hunt for food using the multifunctional tentacles to pry open bivalve mollusks or they use the robustly hooked mandibles for crushing the shells or the hard carapace of the decapods (Wirtz, 2007). The strategy of drilling is less commonly used and is a longer and expensive option. The small holes are drilled using the radula and the salivary papilla which 
has a tooth-like bulge with the function of an "accessory radula" and by chemical secretions from the salivary gland (Nixon, 1980). When the hole is completed, the Octopus injects a toxin, paralyzing the prey before eating it. The outline of the small holes comprises between $0.1 \mathrm{~mm}$ and $2.0 \mathrm{~mm}$ in diameter (Kowalewsky, 1993: 73, Table 1), is variable, from a simple elliptic profile to a polygonal star-like shape, which is caused by a change in direction of the radula during the drilling activity (Robba \& Ostinelli, 1975). Indeed, the form of the octopodid drill holes is comparatively variable (Bromley 1981, 1993): "some octopod drill holes have a very distinctive oval morphology and belong to the ichnotaxon Oichnus ovalis Bromley, 1993 ..., others are more 'cylindrical', filling in the ichnotaxon Oichnus simplex Bromley, 1981 and thus very similar to those produced by muricid gastropod" (Todd \& Harper, 2011: 218), or having more regular outline, as observable for exemple in the specimen GPDG 0175f (Fig. 3B). The position of the drill holes seems to have a selective distribution on the gastropod mollusk shell and on the carapace of the crabs herein (Wirtz, 1988; Key et al., 2002). Commonly, the drill holes on crabs are concentrated near some areas, such as on the branchial or hepatic areas, or on the peduncles of the eyes. Seven specimens of $R$. pliocaenica representing less than $1 \%$ of the total studied decapod assemblage (Garassino et al., 2002), exhibit a small, complete drill hole located on the hepatic and metabranchial regions. These drill holes, having an elongate, ovate to elliptic outline and conical cross section, are characteristic of a typical octopodid traces of predation (Robba \& Ostinelli, 1975) (Fig. 3A-B). This paleontological evidence seems to confirm that this alternative and selective predatory feeding behavior did take place among octopodid cephalopods since the Early Pliocene (Fig. 4). Evidence of the presence of octopodid cephalopods from the Italian Pliocene deposits were previously reported by Robba \& Ostinelli (1975), based on the drill holes in gastropods from Albenga (Savona, NW Italy). These authors pointed out that the very small drill holes on the shells may belong to small sized predators of the order Octopoda (such as individuals of the small genus Eldone) (Boyle \& Knobloch, 1981), living on the shallow muddy bottom, or even, but less probably, from indeterminate forms referable to the Myopsida (Loliginidae). Direct observations on living specimens attest that the (sub)millimeter-sized drill holes are not correlated with the dimension of the predator, but only to the manner of perforation (Nixon, 1980). To date the only cephalopod remain reported from the "La Serra" quarry is an indeterminate and incomplete squid cuttlebone figured among the associated fauna (Garassino et al., 2012; Fig. 3 D; GPDG 0230); however, as reported by Halm et al. (2000), cuttlefish usually prey crabs inflicting a wound in the proximal joint of the hind pereiopods to inject a toxin instead of drilling the carapace dorsally. In Mediterranean Sea Octopus vulgaris and O. macropus are also present in the shallow water sea grass Posidonia beds. Because of the close similarity in size, form, typology, and in absence of others possible drilling predators, creating similar drill holes (Kowalewski, 2002; Table 2), we confidently ascribe these drill holes more likely to those produced by indeterminate octopodid cephalopods possibly belonging from the genera Octopus or Eldone. Finally, we remark that the evidence of predation observed in single species, $R$. pliocaenica, may be related to the behavior and the great abundance of specimens of this species in the hunting environment of octopodids and, possibly, may also have been preferentially selected by the octopodids. This is the first fossil evidence of the direct predation by octopodid cephalopods on decapod brachyurans. 


\section{Acknowledgements}

We wish to thank the members of the Gruppo Paleontologico "C. De Giuli" (GPCD), Castelfiorentino (Firenze) to give us the permission to study the specimens housed in the Biblioteca Comunale Vallesiana Paleontological Collections, Castelfiorentino (Firenze); M. Forli, Società italiana di Malacologia, Prato, for help in determination of the associated malacofauna; and A. A. Klompmaker, Kent State University, Ohio, USA, and Florida Museum of Natural History, University of Florida, Florida, Gainesville, USA, for useful suggestions and careful review and criticism.

\section{References}

Boucot A. J., 1990 - Evolutionary Palaeobiology of Behaviour and Coevolution. Elsevier, New York, 6: 164-167.

Boyle P. R. \& Knobloch D., 1981 - Hole boring of crustacean prey by the Octopus Eledone cirrhosa (Mollusca; Cephalopoda). Journal of Zoology, 193: 1-10.

Bromley R. G., 1981 - Concepts in ichnotaxonomy illustrated by small round holes in shells. Acta Geológica Hispanica, 16: 55-64.

Bromley R. G., 1993 - Predation habits of Octopus past and present and a new ichnospecies Oichnus ovalis. Bulletin of the Geological Society of Denmark, 40: 167-173.

Carriker M. R., 1969 - Excavation of boreholes by the gastropod, Urosalpinx: an analysis by light and scanning electron microscopy. American Zoologist, 9: 917-933.

Carriker M. R., 1981 - Shell penetration and feeding by naticacean and muricacean predatory gastropods: a synthesis. Malacologia, 20: 403-422.

Garassino A., Pasini G., De Angeli A., Charbonnier S., Famiani F., Baldanza A. \& Bizzarri R., 2012 - The decapod community from the Early Pliocene (Zanclean) of "La Serra" quarry (San Miniato, Pisa, Toscana, central Italy): sedimentology, systematics, and paleoenvironmental implications. Annales de Paléontologie, Paris, 98: 1-61.

Grande L., 1984 - Paleontology of the Green River Formation, with a review of the fish fauna. The Geological Survey of Wyoming, Bulletin 63: 1-333.

Grey M., Boulding E. C. \& Brookfield E., 2005 - Shape differences among boreholes drilled by three species of naticid gastropods. Journal of Molluscan Studies, 71 (3): 253-256.

Halm M. P., Agin V., Chichery M. P., Chichery R., 2000 - Effect of aging on manipulative behavior in the cuttlefish, sepia. Physiology \& Behavior 68: 543-547.

Harper E. M., 2002 - Plio-Pleistocene drilling behaviour in scallops from Florida. Palaios, 17: 292-295.

Kabat A. R., 1990 - Predatory ecology of naticid gastropods with a review of shell boring predation. Malacologia, 32: 155-193.

Kelley P. H. \& Hansen T. A., 2003 - The fossil record of drilling predation on bivalves and gastropods. In: Kelley P. H., Kowalewsky M., Hansen T. A. (Eds.), Kluwer Academic / Plenum Publishers, New York: 113-139.

Key L. N., Boyle P. R., \& Jaspars M., 2002 - Novel activities of saliva of the octopus Eledone cirrhosa (Mollusca, Cephalopoda), Toxicon, 40 (6): 677-683.

Kitchell J. A., Boggs C. H., Kitchell F. \& Rice J. A., 1981 - Prey selection by naticid gastropods: experimental tests and application to the fossil record. Paleobiology, 7: 533-552. 
Klompmaker A. A., 2011 - Krabben met boorgaten gezocht. Afzettingen. Werkgroep voor Tertiaire en Kwartaire Geologie, Jaargang, 32 (3): 49.

Klompmaker A. A., 2012 - Drill hole predation on fossil serpulid polychetes, with new data from Pliocene of the Netherlands. Palaeogeography, Palaeoclimatology, Palaeoecology, Elsevier Science Publishers 321-322: 113-120.

Kowalewski M., 1993 - Morphometric analysis of predatory drillholes Palaeogeography, Palaeoclimatology,Palaeoecology, Elsevier Science Publishers 102: 69-88.

Kowalewski M., 2002 - The fossil record of predation: an overview of analytical methods. Paleontological Society Papers, 8: 3-42.

Maisey J. G., 1991 - Santana fossils: an illustrated atlas. Neptune, NJ: T.F.H. Publications.

Maisey J. G. \& De Carvalho M. G. P., 1995 - First Record of Fossil Sergestid Decapods and Fossil Brachyuran crab Larvae (Arthropoda, Crustacea), with remarks on Some Supposed Palaemonid Fossil, from the Santana Formation (AptianAlbian, NE Brazil). American Museum Novitates, New York, 3132: 1-17.

Nixon M., 1979 - Hole boring in shells by Octopus vulgaris in the Mediterranean, Malacologia, 18: 431-444.

Nixon M., 1980 - The salivary papilla of Octopus as an accessory radula for drilling shells. Journal of Zoology, 190: 53-57.

Nixon M. \& Macconnachie E., 1988 - Drilling by Octopus vulgaris (Mollusca: Cephalopoda) in the Mediterranean. Journal of Zoology, 216: 687-716.

Nixon M., 1980 - The salivary papilla of Octopus as an accessory radula for drilling shells. Journal of Zoology, 190: 53-57.

Nybelin O., 1958 - Über die angebliche viviparität bei Trissops formosus Agassiz. Arkive för Zoologi, serie 2, 11: 447-455.

Ossó A. \& Stalennuy O., 2011 - Description of the first fossil species of Bathynectes (Brachyura, Polybiidae) in the Badenian (middle Miocene) of the Medobory Hills (Ukraine, Central Parathetys), with remarks on its habitat ecology. Treballs del Museu de Geología de Barcelona, Barcelona, 18 (2011): 37-46.

Pasini G. \& Garassino A., 2006 - Palaeoecology and feeding evidence of decapod crustaceans on some shells of gastropods from the Pliocene of Masserano (Biella, NW Italy). Atti della Società italiana di Scienze naturali e del Museo civico di Storia naturale in Milano, Milano, 147 (2): 167-182.

Pasini G. \& Garassino A., 2011 - Predation on brachyuran (Crustacea, Decapoda): an unique direct evidence from the Late Cretaceous (Cenomanian) of Hadjoula (Lebanon). Atti della Società italiana di Scienze naturali e del Museo civico di Storia naturale in Milano, Milano, 152 (2): 233-239.

Robba E. \& Ostinelli F., 1975 - Testimonianze di predazione sui molluschi Pliocenici di Albenga. Rivista Italiana di Paleontologia e Stratigrafia, Milano, 81 (3): 309-372.

Todd J. A. \& Harper E. M., 2011 - Stereotypic boring behavior jnferred from the earliest known octopod feeding traces, Early Eocene, southern England. Lethaia, 44: 214-222.

Wirtz P., 2007 - Trapani al veleno. Acquarium Oggi, 5 (4): 8-9.

Wodinsky J., 1969 - Penetration of the shell and feeding on gastropods by Octopus. American Zoologist, 9 (3): 997-1010.

Ricevuto: 12 settembre 2012

Approvato: 4 ottobre 2012 